\title{
JINTAN HITAM SEBAGAI IMUNOMODULATOR DAN ANTI INFLAMASI PADA PASIEN ASMA
}

\author{
Maharani Amanulloh*, Ester Krisdayanti \\ Fakultas Kedokteran, Universitas Lampung, J1. Prof. Dr. Ir. Sumantri Brojonegoro No.1, Gedong Meneng, Kec. \\ Rajabasa, Kota Bandar Lampung, Lampung, Indonesia 35145 \\ *maharani.amanulloh@gmail.com (+6281271192077)
}

\begin{abstract}
ABSTRAK
Jintan hitam merupakan salah satu tanaman herbal yang memiliki berbagai efek farmakologis diantaranya yaitu sebagai antioksidan, antidiabetes, antialergi, antiinflamasi, dan sebagai imunomodulator, sehingga jintan hitam (Nigella sativa) seringkali digunakan sebagai obat herbal. Tujuan literature review ini yaitu untuk mengetahui efek jintan hitam sebagai imunomodulator dan anti inflamasi pada pasien asma. Metode yang digunakan adalah metode literature review dari 47 artikel PubMed NCBI, Google Schoolar, dan Elsevier yang diperoleh hanya 23 artikel yang digunakan dari tahun 2009 hingga tahun 2019. Dari beberapa penelitian yang dilakukan didapatkan hasil bahwa jintan hitam bermanfaat sebagai immunomodulator dengan meningkatkan titer antibodi dan peningkatan limfosit dan monosit serta menurunkan kadar neutrofil. Senyawa aktif yang terdapat di dalam jintan hitam (Nigella sativa) salah satunya yaitu thymoquinone dan thymohidroquinone yang mana senyawa tersebut diketahui dapat mengurangi pemasukan ion kalsium sehingga dapat mengurangi degranulasi sel mast dan sebagai imunomodulator yang dapat menekan reaksi inflamasi.
\end{abstract}

Kata kunci: jintan hitam, immunomodulator, anti inflamasi, asma

\section{BLACK JINTAN AS AN IMMUNOMODULATOR AND ANTI INFLAMATION IN ASMA PATIENTS}

\begin{abstract}
Black cumin (nigella sativa) is one of the herbal plants that has various pharmacological effects including antioxidant, antidiabetic, hypo-allergenic, anti-inflammatory, and as an immunomodulator, so black cumin (nigella sativa) is often used as an herbal medicine. the purpose of this review literature is to determine the effect of black cumin as an immunomodulator and anti-inflammatory in asthma patients. the method used is the literature review method of 47 articles pubmed ncbi, google schoolar, and elsevier obtained only 23 articles used from 2009 to 2019. from several studies conducted it was found that black cumin is useful as an immunomodulator by increasing antibody titers and increased lymphocytes and monocytes and decreased neutrophil levels. active compounds contained in black cumin (nigella sativa), one of which is thymoquinone and thymohidroquinone which compounds are known to reduce the intake of calcium ions so that it can reduce mast cell degranulation and as an immunomodulator that can suppress inflammatory reactions.
\end{abstract}

Keywords: black cumin, immunomodulator, anti-inflammatory, asthma

\section{PENDAHULUAN}

Jintan hitam (Nigella sativa) merupakan salah satu tanaman herbal yang memiliki berbagai efek farmakologis diantaranya yaitu sebagai antioksidan, antidiabetes, antialergi, antiinflamasi, dan sebagai imunomodulator, sehingga jintan hitam
(Nigella sativa) seringkali digunakan sebagai obat herbal (Marlinda, 2015).

Jintan hitam merupakan tanaman herbal yang sudah sering digunakan sebagai obat tradisional, tidak hanya di Indonesia namun juga di negara-negara Timur Tengah 
sebagai promotif kesehatan dan pengobatan berbagai macam penyakit (Hendrik, 2009).

Kandungan senyawa kimia yang terdapat di dalam jintan hitam (Nigella sativa) antara lain yaitu thymoquinone, thymohydroquinone, dithymoquinone, thymol, carvacrol, nigellicine, nigellimine$x$-oxide, nigellidine dan alpha-hedrin. Tymoquinone berfungsi sebagai anti alergi dan antiinflamasi dan juga dapat meningkatkan sistem imun pada penderita asma. Sedangkan thymohidroquinone memiliki efek antibakterial terhadap Staphylococcus aureus, Pseudomonas aeruginosa dan Escherichia coli. Selain itu, dalam sebuah penelitian biji jintan hitam juga dapat menghambat pertumbuhan Candida albicans dan Aspergillus (Marlinda, 2015).

Selain bahan aktif diatas minyak jinten hitam juga mengandung karoten yang diubah oleh lever menjadi vitamin A yang berfungsi sebagai penghancur sel- sel rusak yang dapat menyebabkan kanker, asam amino, protein dan linolenik serta minyak volatile, alkaloid, saponin dan serta tinggi yang memiliki zat antibakteri untuk melawan infeksi parasit sehingga dapat dimanfaatkan untuk mengatasi diare,gangguan lambung, lever dan penyakit lain yang disebabkan olah bakteri. Minyak jinten hitam juga mengandung berbagai mineral kalsium, sodium, potassium, magnesium, selenium dan zat besi yang dibutuhkan dalam jumlah sedikit tetapi memiliki peranan penting dalam membantu fungsi enzim- enzim lainnya dalam menciptakan imunitas tubuh (Ningtyas, 2012).

Asma merupakan penyakit inflamasi saluran nafas kronik yang ditandai dengan batuk, sesak, dan mengi yang terjadi secara episodik dan berulang. Kematian yang disebabkan oleh asma cukup rendah namun insidensinya cukup tinngi dan banyak ditemukan di masyarakat. Berdasarkan data dari World Health Organization (WHO)
100-150 juta penduduk dunia menderita asma dan akan terus meningkat sebesar 180.000 kasus tiap tahunnya (Menkes RI, 2008). Insidensi asma di setiap Negara berbeda, asma merupakan penyebab angka kematian dan kesakitan no. 10 tertinggi di Indonesia berdasarkan Survei Kesehatan Rumah Tangga di berbagai provinsi di Indonesia (Ratnawati, 2011).

Asma merupakan penyakit yang timbul akibat adanya hipereaktivitas dari bronkus dan reaksi inflamasi di saluran pernafasan. Reaksi tersebut muncul ketika terdapat pencetus seperti zat alergen, virus, dan lain sebaigainnya. Ketika zat pencetus masuk ke saluran pernafasan maka akan timbul respon inflamasi akut yaitu reaksi asma dini dan reaksi asma lambat. Jika paparan pencetus berlanjut maka akan timbul reaksi inflamasi sub akut atau kronik. Pada keadaan ini terjadi inflamasi pada bronkus dan sekitarnya berupa infiltrasi sel monosit dan eosinofil ke dinding bronkus dan lumen sekitarnya (Menkes RI, 2008).

Penyempitan saluran nafas pada penderita asma terjadi karena adanya pelepasan mediator inflamasi oleh sel mast dan makrofag sehingga epitel mukosa menjadi lebih permeabel dan memudah zat alergen masuk ke dalam paru-paru dan memperburuk reaksi yang terjadi. Mediator inflamasi secara langsung atau tidak langsung menyebabkan serangan asma, melalui sel efektor sekunder seperti eosinofil, platelet, neutrofil dan limfosit (Menkes RI, 2008). Senyawa aktif jintan hitam (Nigella sativa) yang berfungsi sebagai imunodulator dan anti inflamasi diharapkan dapat menekan reaksi inflamasi yang timbul pada penderita asma.

\section{METODE}

Penulisan ini menggunakan metode studi artikel review. Sumber pustaka yang digunakan yaitu berasal dari penelitianpenelitian terbaru dan buku-buku pedoman mengenai manfaat jintan hitam (Nigella sativa) yang diterbitkan pada tahun 2008 
hingga tahun 2019 dan dapat diakses melalui internet di PubMed NCBI, elseiver, dan Google Scholar. Artikel yang didapatkan sekitar 47 artikel dan hanya 23 artikel yang saya analisis.

\section{HASIL}

Potensi dan prospek Spirulina sebagai zat antikanker terlihat cukup menjanjikan. Hal ini didukung oleh uji preklinis yang telah dilakukan oleh BinMefrij (2008) terhadap tikus yang diinduksi dengan tumor payudara. Hal yang senada telah dilakukan oleh Suko dan Purnawati (2011) dengan menggunakan cell line tumor duktal payudara T47D. Laporan dari penelitian tersebut menunjukkan bahwa ekstrak Spirulina sp terbukti secara bermakna mampu meningkatkan indeks apoptosis cell line T47D. penelitian oleh Syahril et al. (2011) melaporkan bahwa ekstrak kasar etanol Spirulina platensis dapat menghambat sel kanker payudara (MCF7) pada konsentarsi $85 \mathrm{~g} / \mathrm{mL}$. Skrining antikanker oleh Canan (2012) menunjukkan bahwa ekstrak kasar dan fikosianin dari Spirulina hasil kultivasi dengan media Zarrouk mampu menghambat berbagai jenis sel kanker, salah satunya sel MCF-7.

Penelitian oleh Bezerra et al. (2006) dan Nishiumi et al. (2014) menyatakan bahwa senyawa aktif piperidinone, piperidine, hexadecanenitrile merupakan komponen golongan senyawa alkaloid yang berperan dalam penghambatan kanker. Flavonoid termasuk ke dalam senyawa polifenol, metabolit sekunder dari tanaman dan memiliki aktivitas sebagai antikanker. Flavonoid mengandung kuersetin yang berasal dari subkelas flavonol. Kuersetin, genistein atau flavopiridol dapat dijadikan sebagai bahan untuk obat kanker (Ravishankar et al., 2013).

Penelitian Suko dan Purnawati (2011) menunjukkan bahwa pemberian ekstrak Spirulina berpengaruh meningkatkan indeks apoptosis pada sel T47D. Penelitian sebelumnya menunjukkan bahwa fraksi protein Spirulina platensis yang berasal dari air laut memiliki aktivitas antiproliferasi terkuat pada sel MCF-7, HepG-2 dan SGC7901 (Wang and Zhang, 2016). Penelitian oleh Ravi M et al., (2010) dan Anisa A (2019) menyatakan bahwa Aktivitas penghambatan sel MCF-7 dari ekstrak etanol alga spirulina lebih baik dibandingan ekstrak metanolnya.

\section{PEMBAHASAN}

Senyawa kimia jintan hitam (Nigella sativa) memiliki beberapa manfaat diantaranya yaitu sebagai immunomodulator dan anti inflamasi. Manfaat ini dapat digunakan untuk mencegah atau mengobati beberapa penyakit salah satunya asma. Asma merupakan penyakit yang timbul akibat adanya hipereaktivitas dari bronkus dan reaksi inflamasi di saluran pernafasan. Penyempitan saluran nafas pada penderita asma terjadi karena adanya pelepasan mediator inflamasi oleh sel mast dan makrofag sehingga epitel mukosa menjadi lebih permeabel dan memudah zat alergen masuk ke dalam paru-paru dan memperburuk reaksi yang terjadi. Mediator inflamasi secara langsung atau tidak langsung menyebabkan serangan asma, melalui sel efektor sekunder seperti eosinofil, platelet, neutrofil dan limfosit (Menkes RI, 2008).

Berdasarkan keterangan di atas sel mast berperan penting dalam inflamasi saluran nafas pada penderita asma yaitu berperan dalam pelepasan histamin yang memicu respon inflamasi. Senyawa kimia yang terdapat di dalam jintan hitam (Nigella sativa) efektif dalam menghambat pelepasan histamine oleh sel mast. Dari penelitian sebelumnya dijelaskan bahwa thimoquinone (salah satu senyawa aktif di dalam jintan hitam) dapat melemahkan reaksi inflamasi yang ditimbulkan oleh sel mast dengan memblok transkripsi dan produksi $\mathrm{TNF} \alpha$ melalui modulasi faktor transkripsi proinflamatori NF-K $\beta$ (MA, RE, MR, \& SC, 2007). 
Jintan hitam dapat mengurangi pemasukan ion kalsium ke dalam sel, sehingga mengurangi proses degranulasi sel mast dan memiliki aktivitas immunomodulator yang berperan penting dalam stabilisasi Th 1 dan Th 2 yang erat kaitannya dengan reaksi inflamasi. Jintan hitam memiliki kandungan utama yang dinilai memiliki berbagai aktifitas farmakologis yaitu thymoquinon (TQ) dan nigellon (Ramadheni, Wahyuni, Raveinal, \& Khairsyaf, 2014). Nigellon dapat menurunkan histamin darah yang diproduksi sel-sel mast melalui penurunan kadar kalsium $(\mathrm{Ca} 2+)$ intrasel. Thymoquinone berperan menurunkan sitokin-sitokin hasil produksi Th2 yaitu IL4, IL-5 dan IL-13 serta penurunan IgE serum. (Subijanto \& Diding, 2008). Penurunan IL-4 dan IgE serum dapat mencegah respon inflamasi dan juga edema mukosa (Gunel, Meteoglu, Yilmaz, Omurlu, \& Kocaturk, 2017).

Kandungan ekstrak etanol pada jintan hitam juga berperan sebagai agen antiinflamasi pada saluran pernafasan dengan mencegah reaksi dari sel mast dan menurunkan kadar sel darah putih serta punurunan kadar neutrofil. Penurunan kadar neotrofil ini akan menyebabkan penurunan sensitifitas dan kontraktilitas dari trakea sehingga dapat mencegah reaksi inflamasi pada pasien asma (Boskabady, Keyhanmanesh, khamneh, \& Ebrahimi, 2011).

Senyawa kimia yang terdapat di dalam jintan hitam (Nigella sativa) selain berfungsi sebagai agen antiinflamasi juga dapat berfungsi untuk meningkatkan fungsi paru pada pasien asma dengan meningkatnya kadar FEV1, dan FEV25-75. Selain itu senyawa kimia di dalam jitan hitam juga dapat menurunkan kadar $\operatorname{IgE}$ yang akan memicu reaksi alergi, penurunan kadar IgE ini diduga berhubungan dengan peningkatan kadar Interferon- $\gamma$ (Ayad Mohammed Salem, 2017).

Senyawa kimia jintan hitam juga dapat berfungsi sebagai imunomodulaor yaitu untuk memperkuat sistem imun tubuh. Senyawa kimia jintan hitam akan menekan rasio T-cell yang berfungsi sebagai pembunuh sel alamiah. Senyawa kimia jintan hitam menjadikan rasio T-cell positif dan negatif menjadi $55 \%$ berbading $30 \%$, yang mana $30 \%$ sebagai pembunuh sel alamiah (Gilani, Jabean, \& Khan, 2004). Senyawakimia Jintan hitam (Nigella sativa Linn.) juga dapat merangsang dan memperkuat sistem imun tubuh manusia melalui peningkatan jumlah, mutu, dan aktivitas sel-sel imun tubuh. Pemberian ekstrak etanol biji jintan hitam (Nigella sativa) juga dapat meningkatkan antibodi yang merupakan sistem imun dapatan (non spesifik) dan jumlah sel leukosit yang merupakan sistem imun alamiah (spesifik) (Suharti, 2011).

\section{SIMPULAN}

Senyawa kimia yang terdapat di dalam jintan hitam (Nigella sativa) bermanfaat sebagai imunodulator dan anti inflamasi dengan menginhibisi sel mast dalam menghasilkan histamine, menurunkan kadar $\mathrm{IgE}$ dan meningkatkan interferon- $\gamma$ sehingga terjadi perbaikan fungsi paru dan kondisi penderita asma. Selain itu senyawa yang terdapat di dalam jintan hitam juga berfungsi sebagai imunomodulator dengan meningkatkan titer antibody yang terdapat di dalam tubuh.

\section{DAFTAR PUSTAKA}

Ayad Mohammed Salem, d. (2017). Effect of Nigella sativa supplementation on lung function and inflammatory mediators in partly controlled asthma: a randomized controlled trial. ANN SAUDI MED, 37(1), 64-71.

Boskabady, M. H., Keyhanmanesh, R., khamneh, S., \& Ebrahimi, M. A. (2011, Februari). The effect of Nigella sativa extract on tracheal The effect of Nigella sativa extract on tracheal sensitized guinea pigs. CLINICS, 66(5), 879-887. 
Boskabady, M., Mohsenpoor, N., \& Takaloo, N. (2010, Agustus). Antiasthmatic effect of Nigella sativa in airways of asthmatic patients. $J$ Phymed, 17(10), 707-713.

Gilani, A., Jabean, Q., \& Khan, M. (2004). A review of medicinal uses and pharmacological activities of Nigella sativa. Park J Biol Sci, 4, 441-451.

Gunel, C., Meteoglu, I., Yilmaz, M., Omurlu, I., \& Kocaturk, T. (2017). The anti-inflammatory effects of thymoquinone in a rat model of allergic rhinitis. J ear nose trhoat, 27, 226-232.

Hendrik. (2009). Habbatus sauda thibbun nabawi untuk mencegah dan mengobati berbagai penyakit. Solo: Pustaka Iltazam.

Ikhsan, M., Hiedayati, N., Maeyama, K., \& Nurwidya, F. (2018). Nigella sativa is as anti inflammatory agent in asthma. BMC Research Note, 11(744), 1-5.

Keyhanmanesh R, Saadat S, Mohammad M2, Shahbaza AA, \& Fallahi M. (2015, November). The Protective Effect of $\alpha$-Hederin, the Active Constituent of Nigella sativa, on Lung Inflammation and Blood Cytokines in Ovalbumin Sensitized Guinea Pigs. Phytotherapy Research, 29(11).

MA, E. G., RE, M., MR, N., \& SC, D. (2007). Thymoquinone attenuates proinflammatory responses in lipopolysaccharide-activated mast cells by modulating NF-KB nuclear transactivation. Biochim Biophysic Acta, 1770, 556-564.

Marlinda, L. (2015). Efektivitas Ekstrak Etanol Biji Jintan Hitam (Nigella sativa Linn.) Terhadap Peningkatan Fagositosis dalam Respon Imun Tubuh. J Majority, 4(3).
Menkes RI. (2008). Keputusan Menteri Kesehatan Republik Indonesia Nomor 1023/MENKES/SK/XI/2008 Tentang Pedoman Pengendalian Penyakit Asma. Jakarta: Menteri Kesehatan Indonesia.

Ningtyas, E. A. (2012). Aktivasi pemakaian jinten hitam (nigella sativa) terhadap respons imun pada gigi yang mengalami inflamasi. stomatognatic (J.K.G Unej), 9(1), 48-53.

Ramadheni, P., Wahyuni, F., Raveinal, \& Khairsyaf, O. (2014). Pengaruh pemeberian sediaan minyak biji jintan hitam (Nigella sativa L) peroral Peroral Terhadap Nilai Hitung Jenis Sel pada Pasien Asma. Prosiding Seminar Nasional dan Workshop "Perkembangan Terkini Sains Farmasi dan Klinik IV", (pp. 165171).

Ratnawati. (2011). Editorial : epidemiology of asthma. J Respir Indo, 31(4), 172175 .

Subijanto, A., \& Diding, H. (2008). Pengaruh Minyak Biji Jinten Hitam (Nigella Sativa L.) terhadap Derajat Inflamasi Saluran Napas. Majalah Kedokteran Indonesia, 58(6), 200204.

Xinming, S., Yuan, R., Na, Y., Lingfei, K., \& Jian, K. (2016, September). Thymoquinone inhibits inflammation, neoangiogenesis and vascular remodeling in asthma mice. International Immunopharmacology, 38, 70-80. 
Jurnal Penelitian Perawat Profesional, Volume 1 No 1 Hal 115 - 120, November 2019 Global Health Science Group 